\title{
MEMBANGUN KREATIFITAS DAN KEMANDIRIAN PADA ANAK ASUH RUMAH AMALIA JL. SUBAGYO IV BLOK II, NO.24 KOMPLEK PERURI, CILEDUG, TANGERANG - BANTEN
}

\author{
Muger Apriansyah*, Irmal, Budi Prabowo \\ Dosen Fakultas Ekonomi Universitas Pamulang \\ Email* : muger.unpam@gmail.com
}

\begin{abstract}
ABSTRAK
Tujuan Tujuan pelatihan ini adalah untuk membangun kreatifitas, membangun kemandirian, memberikan semangat dan motivasi bagi anak-anak asuh dalam menjalani kehidupannya.

Teknik pendekatan dilakukan dengan metode penyuluhan dan simulasi secara oral dengan permainan edukatif dan tanya jawab.

Hasil kegiatan dapat meningkatkan kreatifitas dan kepercayaan diri dalam menjalani kehidupan tanpa ketergantungan dengan orang lain.
\end{abstract}

\section{Kata Kunci : Kreatifitas, Kemandirian}

\section{PENDAHULUAN}

Daya saing bangsa khususnya daya saing sumber daya manusia (SDM) merupakan hal yang penting bagi sebuah negara di era globalisasi. Pembentukan daya saing SDM tersebut bisa melalui pendidikan baik sekolah maupun perguruan tinggi. Guna menciptakan hal tersebut setidaknya ada dua hal yang harus ditanamkan di dunia pendidikan Indonesia yakni kreatifitas dan kemandirian. Pendidikan yang memuat aspek menumbuhkan kreatifitas akan menciptakan siswa yang berpikir out of box serta bisa memecahkan masalah sedangkan aspek kemandirian akan membuat para siswa tidak selalu bergantung pada orang lain dan mampu berdiri sendiri.

Ada beberapa hal yang bisa dilakukan untuk menciptakan kreatifitas dan kemandirian tersebut. Pertama, Sistem pendidikan di Indonesia sebaiknya lebih diarahkan sejak dini agar para siswa memiliki kompetensi yang bagus dan dapat bersaing, terkhusus untuk menghadapi era globalisasi.

Sedangkan untuk mencapai kemandirian baiknya ada kurikulum kewirausahaan atau pelajaran kemandirian lainnya semenjak sekolah dasar. Karena hal tersebut berguna untuk melatih dan membiasakan generasi muda untuk berwirausaha dan mandiri sejak dini. Hal ini menjadi sangat penting mengingat dan 
melihat data jumlah pengangguran di negeri ini cukup banyak, dikarenakan jumlah lapangan kerja yang tersedia tidak sebanding dengan permintaan pekerjaan yang ada.

Di samping perbaikan dari sistem pendidikan, akan semakin baik jika disertai dengan kesadaran para pelajar bahwa mereka memiliki peran yang penting untuk membangun dan memajukan bangsa ini di tengah arus globalisasi yang semakin deras.

Rumah Amalia adalah rumah belajar untuk anak yatim dan anak kaum dhuafa. Rumah Amalia didirikan sebagai bentuk kepedulian terhadap mereka yang terbatas dalam masalah ekonomi, perhatian dan bimbingan psikologis, akses terhadap pendidikan dan kurangnya ketersediaan bagi perkembangan minat dan bakat anak. Yayasan Rumah Amalia berada di Jalan Subagyo IV Blok II, No. 24 Komplek Peruri, Ciledug, Tangerang. Rumah Amalia juga fokus pada pendampingan dan pemulihan untuk anak-anak yang kehilangan orangtua, putus harapan dan kurang perhatian.

Dengan adanya materi ini tentang dampak diharapkan anak-anak tersebut mampu membangun kreatifitas dan kemandirian untuk menciptkan masa depan yang baik dan bermanfaat untuk orang lain. Oleh karena itu ,Perlu adanya dukungan dari pihak Yayasan untuk menjalankan pelatihan ini agar tersampaikan dengan maksimal.

\section{PERUMUSAN MASALAH}

Berdasarkan latar belakang tersebut, kami dari Tim Program Pengabdian Masyarakat (PKM) Universitas Pamulang (UNPAM) yang berjumlah 10 dosen terpanggil untuk ikut serta membantu memberikan penyuluhan dan terkait materi "Membangun Kreatifitas Dan Kemandirian Pada Anak Asuh Rumah Amalia". yang beralamatkan Jl. Subagyo IV Blok II, No. 24 Komplek Peruri, Ciledug, Tangerang, Banten. Membekali anak-anak untuk dapat membangun kreatifitas dan kemandirian.

\section{TUJUAN PROGRAM}

Tujuan Tujuan pelatihan ini adalah untuk membangun kreatifitas, membangun kemandirian, memberikan semangat dan motivasi bagi anak-anak asuh dalam menjalani kehidupannya.

\section{KEGIATAN}

Persiapan yang dilakukan adalah segala hal yang terkait dengan materi, bahan dan alat sesuai dengan tema secara baik. Hasil persiapan tersebut 
dimaksudkan agar materi tersampaikan dengan dan mudah dimengerti serta dipahami oleh anak-anak di Rumah Amalia.

Adapun pelaksanaan dari kegiatan adalah sebagai berikut:

Waktu Pelaksanaan Kegiatan : Hari Jum'at, Sabtu, dan Minggu.

Tanggal

: 13-15 April 2018

Tempat

: Rumah Amalia, Jl. Subagyo IV Blok II, No. 24

Komplek Peruri, Ciledug, Tangerang, Banten.

\section{APLIKASI}

A. Kreatif

"Kreativitas adalah suatu kemampuan untuk menyelesaikan masalah yang member kesempatan individu untuk menciptakan ide2 asli/adaptif fungsi kegunaannya secara penuh untuk berkembang" (Widyatun,1999)

"Kreatifitas adalah kemampuan untuk menentukan pertalian baru, melihat subjek dari perspektif baru, dan menentukan kombinasi-kombinasi baru dari dua atau lebih konsep yang telah tercetak dalam pikiran" (James R. Evans, 1994)

"Kreatifitas adalah suatu kemampuan berpikir ataupun melakukan tindakan yang bertujuan untuk mencari pemecahan sebuah kondisi ataupun permasalahan secara cerdas, berbeda (out of the box), tidak umum, orisinil, serta membawa hasil yang tepat dan bermanfaat" (inginhilangingatan, 2009)

B. Inovatif

"Inovatif yaitu Usaha seseorang-dengan mendayagunakan pemikiran, kemampuan imajinasi, berbagai stimulan, dan individu yang mengelilinginya — dalam menghasilkan produk baru, baik bagi dirinya sendiri ataupun lingkungannya."

"Inovatif yaitu Kemampuan seseorang dalam mendayagunakan kemampuan dan keahlian untuk menghasilkan karya baru."

"Berpikir inovatif yaitu Proses berpikir yang menghasilkan solusi dan gagasan di luar bingkai konservatif."

C. Syarat-syarat berpikir inovatif

- Elastisitas yang tinggi

- Produktivitas yang tinggi

- Orisinalitas yang tinggi

- Sensitivitas yang tinggi

D. Syarat-syarat inovasi

- Menghasilkan produk yang bermanfaat bagi masyarakat dan lingkungannya. 
- Menghasilkan produk yang relatif baru.

- Menghasilkan produk yang memenuhi kebutuhan individu ataupun kelompok.

"Inovatif adalah suatu kemampuan manusia dalam mendayagunakan pikiran dan sumber daya yang ada disekelilingnya untuk menghasilkan suatu karya yang benar-benar baru yang orisinil, serta bermanfaat bagi banyak orang" (inginhilangingatan, 2009)

kesimpulannya bahwa, kreatif dan inovatif itu sangatlah diperlukan dalam kehidupan sehari hari. Karena kreatif dan inovatif itu sangat menentukan kualitas hidup kita, kita dituntut untuk memiliki jiwa yang kreatif inovati karena keduanya akan menentukan hasil usaha kita.

E. Kemandirian

Kemandirian merupakan salah satu aspek yang gigih diperjuangkan oleh setiap remaja sebagaimana sebuah ungkapan yang disampaikan oleh Fasick (dalam Steinberg, 1993) "one goal of every adolescent is to be accepted as an autonomous adult".

Kemandirian menurut Bahara (dalam Fatimah, 2006) berarti hal atau keadaan seseorang yang dapat berdiri sendiri tanpa bergantung pada orang lain. Kata kemandirian berasal dari kata dasar diri yang mendapat awalan ke dan akhiran an yang kemudian membentuk arti yang mengacu pada suatu keadaan dimana seseorang dapat melakukan sesuatu tanpa bantuan orang lain (Kamus Besar Bahasa Indonesia Edisi III, 2001). Menurut Parker (dalam Ali, 2005) kemandirian juga dapat diartikan sebagai suatu kondisi seseorang yang tidak bergantung kepada otoritas dan tidak membutuhkan arahan secara penuh. Menurut Setiyawan (dalam Yusuf, 2001), kemandirian adalah keadaan seseorang yang dapat menentukan diri sendiri dan dapat dinyatakan dalam tindakan atau perilaku seseorang yang dapat dinilai. Arti ini memberikan penjelasan bahwa kemandirian menunjuk pada adanya kepercayaan akan kemampuan diri untuk menyelesaikan persoalan-persoalan tanpa bantuan khusus dari orang lain, keengganan untuk dikontrol orang lain, dapat melakukan sendiri kegiatan-kegiatan dan menyelesaikan sendiri masalah-masalah yang dihadapi.

Menurut Lamman (dalam Fatimah, 2006) menyatakan bahwa kemandirian merupakan suatu kemampuan individu untuk mengatur dirinya sendiri dan tidak tergantung kepada orang lain. Hal yang senada juga diungkapkan oleh Brawer (dalam Havinghurts, 1993) bahwa kemandirian merupakan perilaku yang terdapat pada seseorang yang timbul karena dorongan dari dalam dirinya sendiri, bukan karena pengaruh orang lain. Menurut Steinberg (1993) remaja yang memperoleh 
kemandirian adalah remaja yang memiliki kemampuan untuk mengatur diri sendiri secara bertanggung jawab, meskipun tidak ada pengawasan dari orang tua ataupun guru. Kondisi demikian menyebabkan remaja memiliki peran baru dan mengambil tanggung jawab baru, sehingga hal ini akan menempatkan remaja untuk menjadi tidak tergantung pada orang tua untuk memperoleh kemandirian secara penuh sehingga masalah kemandirian secara spesifik menuntut suatu kesiapan individu baik secara fisik maupun emosional untuk mengatur, mengurus, dan melakukan aktivitas atas tanggung jawabnya sendiri tanpa banyak tergantung pada orang lain. Menurut Maslow (dalam Ali, 2005) bahwa kemandirian merupakan salah satu dari tingkat kebutuhan manusia yang disebut sebagai kebutuhan otonomi. Ia juga menambahkan bahwa seorang yang mencapai aktualisasi diri memiliki sifat-sifat khusus pengaktualisasi yang salah satunya yaitu kebutuhan akan privasi dan independensi, dimana orang yang mengaktualisasikan diri dalam memenuhi kebutuhannya tidak membutuhkan orang lain. Sehubungan dengan itu menurut Beller (dalam Ali, 2005), orang yang mempunyai kemandirian rendah biasanya memiliki ciri khusus antara lain mencari bantuan, mencari perhatian, mencari pengarahan, dan mencari dukungan pada orang lain.

Dari pengertian-pengertian di atas maka dapat disimpulkan bahwa kemampuan melepaskan diri dari ketergantungan emosi pada orang lain terutama orangtua, mampu mengambil keputusan dan berkomitmen pada keputusan yang diambil, serta mampu bertingkah laku sesuai nilai yang diyakini dan berlaku pada lingkungan.

\section{STRATEGI}

Dalam rangka melaksanakan salah satu Tri Dharma Perguruan Tinggi, Dosen Serta Mahasiswa Program Studi S1 Manajemen, Universitas Pamulang kembali melaksanakan kegiatan pengabdian kepada masyarakat (PKM) di Rumah Amalia, yang beralamat di J1. Subagyo IV Blok ii, No. 24 Komplek Peruri, Ciledug, Tangerang, Banten. Pada hari Jumat-Minggu/13-15 April 2018 yang lalu.

PKM yang beranggotakan sebanyak 10 dosen S1 Manajemen, UNPAM di bantu dengan mahasiswa ini tergerak untuk melakukan penyuluhan di rumah yatim. Tema yang diangkat pada kegiatan ini ialah "Membangun Kreatifitas Dan Kemandirian Pada Anak Asuh Rumah Amalia". Juga memberikan cara bagaimana mengali dan menciptakan kreatifitas secara "FUN TRERAPY". Mengapa secara "FUN TRERAPY”?, hal ini di sebabkan karena peserta yang hadir disana rata-rata adalah anak-anak yang usianya 7 hingga 17 tahun. Jumlah keseluruhan anak-anak yang berada di Rumah Amalia ini sebanyak 90 anak yatim dan anak dari kaum duafa. Anak Asuh Rumah Amalia yang di pimpin oleh Bpk. 
Muhammad Agus Syafii berdiri dari tahun 2006, namun diresmikan menjadi yayasan Non-Profit pada tahun 2011.

Selain kreatifitas, anak-anak di sana di ajarkan untuk berinovasi dan kemandiri dalam menjalan kehidupan. Banyak dari anak-anak yang berada di Rumah Amalia yang memang membutuhkan perhatian lebih, ini di sebabkan karena mereka mendapatkan perlakuan kurang baik di rumah khususnya mupun lingkungan pada umumnya.

\section{PENUTUP}

Pelaksanaan kegiatan Pengabdian Kepada Masyarakat oleh Lembaga Penelitian dan Pengabdian Masyarakat (LPPM) Universitas Pamulang yang dilakukan oleh dosen-dosen program studi Manajemen telah berjalan dengan lancar dan mendapat sambutan hangat dari tempat pelaksanaan kegiatan.

Harapan kami dengan pengabdian ini dapat membuka wawasan bagi anak-anak, sehingga dapat membantu dan meningkatkan tingkat keilmuan dan keperibadian yang baik secara rohani dan jasmani sehat yang akan sangat bermanfaat dalam kehidupan mereka pada masa yang akan datang.

\section{DAFTAR PUSTAKA}

Ali, M.2005. Psikologi Remaja (Perkembangan Peserta Didik), Jakarta: Rineka Cipta

Fatimah, E. 2006. Psikologi Perkembangan. Bandung: CV Pustaka Setia

Hurlock, E. B. 2000. Psikologi Perkembangan. Jakarta : Erlangga.

Musdalifah.2007. Perkembangan Remaja dalam Kemandirian (Hambatan Psikologis dependensi terhadap orang tua). Jurnal Pendidikan dan Psikologi Perkembangan. Vol 4.

Sarwono, Sarlito Wirawan. 1998. Psikologi Sosial. Jakarta: Rineka Cipta.

Santrock, J.W. 2003. Perkembangan Remaja. Edisi ke enam. Penerjemah : Shinto B. Adelar dan Sherly Saragih. Jakrta : Erlangga.

https://www.indorelawan.org/organization/5662f6b029a350b3478b8cdf.

https://www.kompasiana.com/ekogenshter/552feef86ea834b36b8b45ac/pengertia n-kreatif-dan-inovatif 
DOKUMENTASI FOTO KEGIATAN
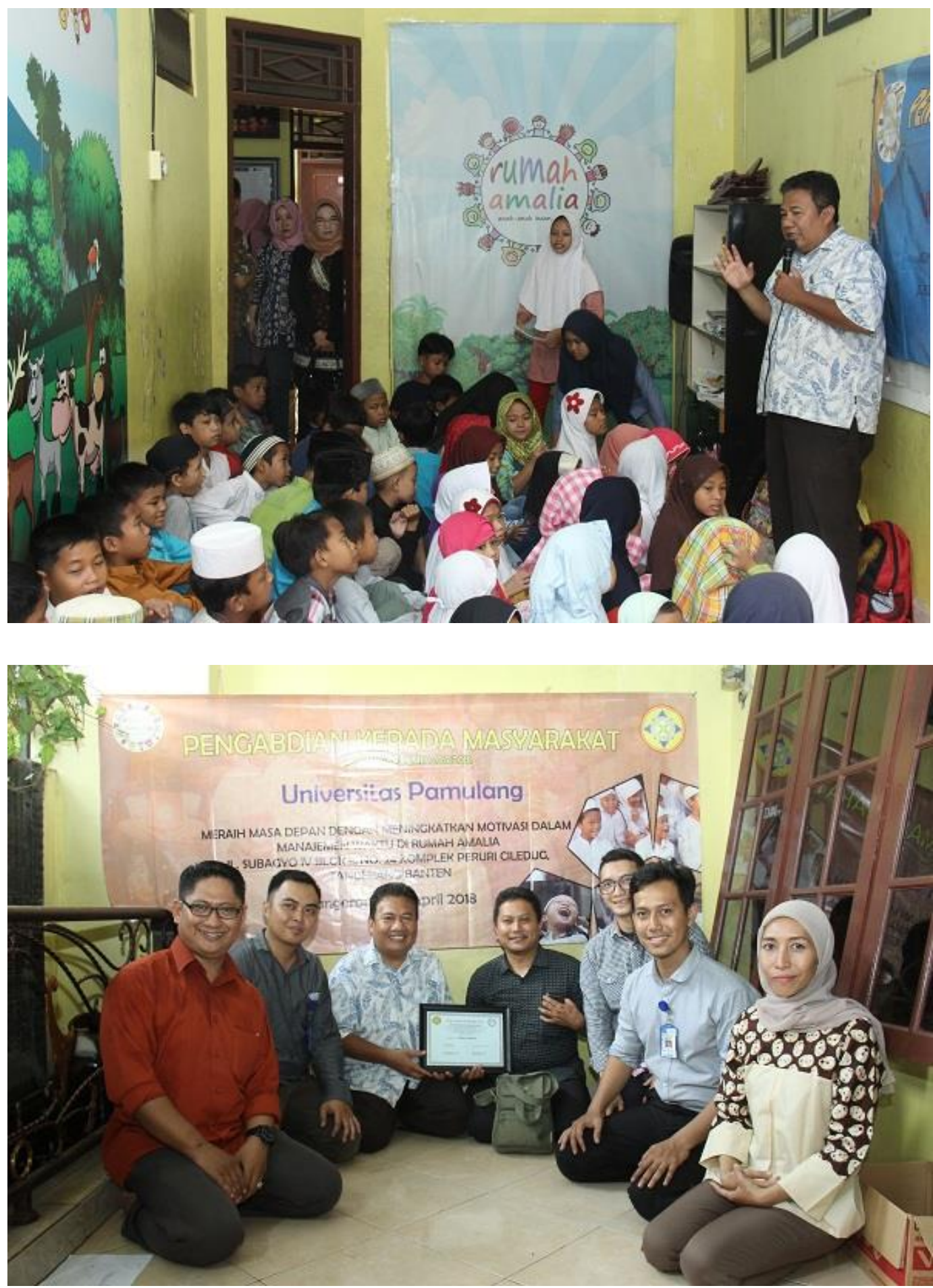


\section{PANDUAN SINGKAT BAGI PENULIS JURNAL DHARMA LAKSANA}

Panduan penulisan ini dimaksudkan untuk menyeragamkan bentuk penulisan karya ilmiah yang dikirim penulis ke redaksi Jurnal Jenius, dengan panduan penulisan sebagai berikut :

1. Naskah ditulis dalam Bahasa Indonesia dengan Abstrak Bahasa Indonesia atau Bahasa Inggris dalam bentuk Font 12" dengan ukuran 1 Spasi dengan intisari tidak lebih dari 250 kata disertai 3 atau 4 kata kunci (keyword).

Naskah berupa Softcopy program MS maksimal 10 Halaman termasuk tabel dan gambar, spasi 1.

2. Sistematika penulisan disusun dengan urutan sebagai berikut :

a) Judul, nama dan alamat email penulis/peneliti tunggal.

b) Abstrak dan intisari, keyword dan kata kunci.

c) Batang Tubuh :

1). Pendahuluan, termasuk didalamnya intisari permasalahan

2). Perumusan Masalah

3). Tujuan Penelitian

4). Aplikasi

5) Penutup

6) Daftar Pustaka atau Referensi

7) Seluruh isi tersebut di buat dengan 1 kolom

3. Judul ditulis dalam bentuk font Times New Roman 12" dengan huruf besar kecil dicetak tebal dan ditempatkan ditengah halaman, serta tidak lebih dari 18 kata.

4. Tulisan karya ilmiah dalam bentuk font Times New Roman 12" dengan ukuran spasi 1,0 spasi dalam bentuk kolom.

5. Gambar diberi nomor dan keterangan, sedangkan tabel diberi nomor dan keterangan diatasnya.

6. Penulisan persamaan matematika yang terdapat pada halaman naskah hendaknya menggunakan equation editor.

7. Daftar pustaka hanya memuat literature yang dirujuk dalam keterangan dan dicantumkan pada bagian akhir naskah dilakukan dengan memberikan nomor.

8. Margin atas dan kiri $4 \mathrm{~cm}$, kanan dan bawah $3 \mathrm{~cm}$, dan ukuran kertas $\mathrm{A} 4$.

9. Dokumentasi Foto kegiatan maksimal 3. 